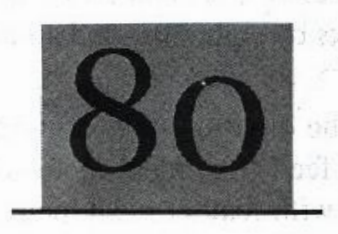

\title{
The response of Tilapia niloticus fed on different feeds composition
}

\author{
Ogunbona, A. A. / Ijimakinde, B.
}

\begin{abstract}
Ninety juveniles of Tilapia niloticus were fed on three different composed diets, the locally compounded feeds with fish meal inclusion, the control, the second treatment were fed on imported feed (2) and treatment (3) with locally compounded feed with feather meal inclusion. At the end of eight weeks it was found out that fish under treatment (1) had the highest feed intake than those of treatment 2 and 3. The weight gained in treatment 2 was higher than 1 and 3. The survival rate were high in this experiment hut the means were not significantly different $(P>0.05)$. (The higher survival rates were attributable to the range of the physiochemical measurement). The weight gained was attributed to the palatability of the floating nature of the feed. The trealment 3 had the lowest weight gained which might be due to the low palatability as a result of feather meal inclusion in the feed. The feed conversion ratio in treatment 2 was highest subsecuently followed treatments 2 and 3 respectively.
\end{abstract}

Keywords: Tilapia niloticus, feather meal, survival rate, growth parameters.

\section{Introduction}

A quaculture is the rearing of water organisms that are beneficial to man-kind in a confined or controlled environment. One of the great advantages of Tilapia for aquacultures is that they feed on a low trophic level. Tilapia are currently divided into three major taxonomic groups based primarily on their reproductive behavior which are the substrate incubator (Tilapia spp) maternal mouth brooder (Oreochromis spp) and paternal or bi-parental mouth brooder (Sarotherdon $s p p)$. The members of the genius Oreochromis feed on algae, aquatic plant, small invertebrate, detrital material and the associated bacterial films. This provides an advantage to farmer because the fish can be reared in extensive system that depends upon the natural productivity of a water body or in intensive system that can be operated with lower feeds cost (Jauncey, 1998).

Tilapia species whose taxonomy has undergone some changes are known to feed on a wide variety of food material (Trewavas 1999). Bowen (2001) reported that Tilapia species may ingest animal material but usually doesn't constitute a significant proportion of the fish total food intake. The diets of Tilapia species have been reported to vary with fish size and time or season of the year (Adesalu 2004).

Fish is one of the cheapest sources of animal protein when compared to beef and chicken. Thus, it is widely consumed by both rich and poor and also the demand for fish outstripped its supply. Fish farming has shown remarkable $20 \%$ increase in growth per year for the past six years, with highest growth in small-to-medium enterprises, and a number of large scales inlensively managed fish farms, Together with Egypt and South Africa, Nigeria is now one of the most significant and strongly growing aquaculture producers in the region. Nigeria's fast growing in aquaculture is a replication of that observed in other regions where the market has been a long in driving growth (FAO, 2004). Hence the study is designed to determine the response of T. niloticus to different types of fced, fed on imported pelletized feed, local y compounded feed and Feather Meal as Inclusion with the feed in glass tank, since it is known that Tilapia are mostly rearec in earthen pond and they feed on natural diets, which is a free supply from the pond.

The objective of the project:

1. To evaluate the growth performance of juvenile $T$. niloticus in glass tank.

2. To determine the survival rate of $T$. niloticus fed on imported feed, locally feed and feather meal inclusion feed respectively. 


\section{Materials and Methods}

The project was carried out at the Fisheries Technology Department, School of Agriculture, Lagos State Polytechnic Ikorodu Campus. The experiment was carried out in three (3) glass tank, each divided into three (3) replicate having a volume of

$0.178 \mathrm{~m}^{3}$. Before the commencement of the experiment, the tanks were washed, cleaned and filled with water to about three quarter of its volume.

- Stocking of experimental fish: Ninety juveniles of Tilapia niloticus were used for the experiments which were purchased from a reputable farm at Badagry. Each of the tanks replicate contained ten (10) juveniles of tilapia niloticus and was randomly assigned to experimental diets treatment.

- Physical and chemical parameters: Physio-chemical parameters were monitored and analyzed with Bauch and Lamb field analysis kit. Parameters such as Water $\mathrm{pH}$, Dissolved Oxygen, Temperature and Ammonia were analyzed. Dissolved Oxygen was improved by using aerator for proper and effective circulation of oxygen in all the glass tanks for the fishes. Also, changing of water was done every two (2) days by siphoning and adding new water to prevent pollution.

- Fecding of the fish: The fish was fed with the experimental diets daily for the duration of two months. And they were properly fed. Treatment One (control) contained locally compounded feed (fish meal inclusion), treatment Two with imported feed and Treatment Three was locally compounded feed with feather meal inclusion (at $14.5 \%$ inclusion). The feed was served at a fixed point in the glass tank at each feeding time and was served twice daily (in the morning and in the evening). The total weight of feed consumed per each feeding trial and total body weight of fish were recorded every weck.

- Experimental Design: Complete randomized design (CRD) method was used. The experiment consists of three treatments and three replicate.

- Composition of experimental dicts: The choice of the ingredients was based on the content of the essential dietary nutrient and their availability and price. The local feed was prepared using the following ingredient: fish meal, maize, wheat, offal, groundnut cake, soya bean, blood meal, spaghetti, salt, fish premix and vitamin $\mathrm{C}$ while the feather meal inclusion feed contained the entire ingredient in the local feed with the inclusion of hydrolyzed feather meal and the imported feed was brought from the market at Sabo, Ikorodu.

Table 1: Composition of experimental diets $\mathrm{g} / 100 \mathrm{~g}$.

\begin{tabular}{l|l|l|c|}
\hline $\begin{array}{l}\text { Ingredient } \\
\text { Maize }\end{array}$ & $\begin{array}{l}\text { Diet 1 } \\
\text { Local feed }\end{array}$ & $\begin{array}{l}\text { Diet 2 } \\
\text { Imported feed } \\
\text { NA* }\end{array}$ & $\begin{array}{l}\text { Diet 3 } \\
\text { Feather meal inclusion feeds* }\end{array}$ \\
\hline Wheat offal & 10 & NA & 12 \\
\hline Groundnut cake & 5 & NA & 5 \\
Soybean & 18 & NA & 18 \\
Fish meal & 36 & NA & 36 \\
Blood meal & 20 & NA & 0 \\
\hline Spaghetti & 5 & NA & 5 \\
Salt & 5 & NA & 5 \\
Fish premix & 0.25 & NA & 0.25 \\
\hline Vitamin c & 0.25 & NA & 0.25 \\
Feather meal & 0.50 & NA & 0.50 \\
& 0 & NA & 18 \\
\hline & $100 \mathrm{Kg}$ & \multicolumn{2}{|c|}{} \\
\hline
\end{tabular}

$N A^{* *}-$ Not available

Table 2: Proximate analysis of experimental diets.

\begin{tabular}{|c|c|c|c|}
\hline Ingredient & $\begin{array}{l}\text { Diet } 1 \\
\text { Local feed }\end{array}$ & $\begin{array}{l}\text { Diel } 2 \\
\text { imported feed }\end{array}$ & $\begin{array}{l}\text { Diet } 3 \\
\text { Feather meal inclusion feeds }\end{array}$ \\
\hline Crude protein & 44.36 & 45 & 44.56 \\
\hline Energy (Kcal) & 2806 & - & 2809.7 \\
\hline Fiber $\%$ & 3.89 & 1.5 & 4 \\
\hline Fat $\%$ & 3.74 & 12 & 4.09 \\
\hline Calcium & 1.35 & - & 0.1 \\
\hline Phosphorus & 0.88 & 1.2 & 0.33 \\
\hline
\end{tabular}

\section{Data Collection and Analysis}

The weight gain, feed intake, survival rate and feed conversion ratio were measured on a weekly basis to determine the effect of the experimental diet on the fishes. Also data were collected and analyzed using analysis of variance.

$$
\text { i. Weight Gain }=\text { Final Weight }- \text { Initial Weight }
$$$$
\text { ii. Percentage mortality }=\frac{\text { Number of stock }- \text { number of remrant }}{\text { Number of stock }} \times 100
$$ 
iii. Feed Conversion Ratio $=$ Weight Gain $/$ Feed Intake

\section{Results and Discussion}

Physio-chemical parameters

- Water temperature: The water temperature ranged from 24 to $30^{\circ} \mathrm{C}$ for the treatment.

- pH of water: The $\mathrm{pH}$ ranged from 6.4 to 8.0 for the treatment.

- Dissolved oxygen: The dissolved oxygen ranged from 5.0 to $9.0 \mathrm{mg} / \mathrm{l}$ for the treatment.

- Average feed intake:

Table 4.1.2: Average feed intake (G)/Fish/Week

\begin{tabular}{l|r|r|r}
\hline Week & $T_{1}$ & $T_{2}$ & $T_{3}$ \\
\hline 1 & 2.29 & 5.96 & 3.26 \\
2 & 4.10 & 3.05 & 1.93 \\
3 & 3.92 & 2.24 & 2.27 \\
4 & 3.92 & 2.20 & 3.39 \\
5 & 3.33 & 3.43 & 3.90 \\
6 & 4.70 & 1.40 & 2.23 \\
7 & 5.00 & 2.67 & 1.57 \\
8 & 4.27 & 3.50 & 1.47 \\
$\sum X$ & 31.53 & 24.45 & 19.02 \\
\hline$X$ & 3.94 & 3.06 & 2.38 \\
\hline
\end{tabular}

- The average feed intake $\mathrm{g} /$ fish/week was shown in table 4.1.2 above. Fish on Treatment 1 (Local Feed) had the highest feed intake of $3.94 \mathrm{~g}$ followed by $\mathrm{T}_{2}$ and $\mathrm{T}_{3}$ with the intake value of 3.06 and 2.38 respectively. Statistical analysis revealed that there was no significant difference $(\mathrm{P}>0.05)$ in the overall average feed intake of the fishes. It was noted that there was differences in the value with T3 having the lowest feed intake. This may be attributed to the low palatability of the feather meal which was carlier reported by Ayanwale (2006), who fed rabbit with feather meal based diet.

Average weight gain (g):

Table 3: Average weight gain (g)/fish/week.

\begin{tabular}{l|c|c|c}
\hline Week & $T_{1}$ & $T_{2}$ & $T_{3}$ \\
\hline 1 & 3.17 & 5.83 & 1.33 \\
\hline 2 & 3.98 & 6.39 & 1.00 \\
\hline 3 & 3.79 & 2.13 & 1.83 \\
4 & 2.37 & 3.38 & 3.78 \\
5 & 3.50 & 2.70 & 2.20 \\
6 & 2.50 & 1.07 & 1.80 \\
\hline 7 & 2.00 & 2.70 & 2.43 \\
$\underline{8}$ & 2.00 & 2.90 & 2.10 \\
$\underline{\Sigma} X$ & 23.31 & 27.10 & 16.47 \\
$\underline{X}$ & 2.91 & 3.39 & 2.06 \\
\hline
\end{tabular}

- Table 4.1.3 shows the average weight gain in (g)/fish/week of the treatment. Statistical analysis revealed that there was no significant difference ( $\mathrm{P}>0.05$ ) in the overall average weight gain of fishes. (Appendix II), Fish on Treatment 2 (imported feed) had the highest average weight gain of $3.39 \mathrm{~g}$ per fish/week. Fish on Treatment 1 had average weight gain of $2.91 \mathrm{~g}$ while fish on $\mathrm{T} 3 \mathrm{had}$ the lowest weight gain of $2.06 \mathrm{~g}$.

- Survival rate: $\mathrm{C}$

Tabie 4: Survival rate per treatment/week.

\begin{tabular}{l|l|ll|l}
\hline \multicolumn{1}{c|}{ Week } & \multicolumn{1}{c|}{$\mathrm{T}_{1}$} & $\mathrm{~T}_{2}$ & \multicolumn{1}{c}{$\mathbf{T}_{3}$} \\
\hline 1 & 30 & 30 & 30 \\
\hline 3 & 28 & 28 & 30 \\
\hline 4 & 22 & 28 & 30 \\
5 & 20 & 28 & 30 \\
6 & 20 & 28 & 29 \\
7 & 20 & 28 & 28 \\
8 & 19 & 27 & 26 \\
$\Sigma X$ & 18 & 27 & 25 \\
$X$ & 177 & 224 & 228 \\
\hline
\end{tabular}


Table 5: Percentage survival rate.

\begin{tabular}{llll}
\hline & $T_{1}$ & $T_{2}$ & $T_{g}$ \\
\hline Initial slocking rate of juveniles per tank & 30 & 30 & 30 \\
\hline Final Stocking Rate/No. of juveniles per tank & 18 & 27 & 25 \\
\hline Percentage mortality & $40 \%$ & $10 \%$ & $16.7 \%$ \\
\hline Percentage survival rate & $60 \%$ & $90 \%$ & $83.3 \%$ \\
\hline
\end{tabular}

- Table 4.1.4 above shows the survival rate of the fishes fed in the experimental diet. Fish on Treatment 3 had the highest survival rate of 28.5 followed by Treatment 2 and Treatment 3 with survival rate of 28 and 22.12 respectively while Treatment 2 had the highest percentage survival rate as shown in the table 4.5 . Statistical analysis revealed that there is no significant difference $(P>0.05)$ among the treatment mean. (Appendix IV).

- Average feed conversion ratio:

Table 6: Average feed conversion ratio/week.

\begin{tabular}{l|c|c|c}
\hline Week & T1 & T2 & T3 \\
\hline 1 & 1.38 & 0.98 & 0.41 \\
2 & 0.97 & 2.09 & 0.41 \\
\hline 3 & 0.97 & 0.95 & 0.81 \\
\hline 4 & 0.60 & 1.54 & 1.58 \\
\hline 5 & 1.05 & 0.79 & 0.56 \\
6 & 0.53 & 0.76 & 0.81 \\
\hline 7 & 0.40 & 1.01 & 1.54 \\
\hline 8 & 0.47 & 0.83 & 1.42 \\
\hline$X$ & 6.37 & 8.95 & 7.65 \\
\hline & 0.80 & 1.11 & 0.96 \\
\hline
\end{tabular}

- The table shown above contained the feed conversion ratio of the fishes feed with the experimental diets. Fish on Treatment 2 (imported feed) had high feed conversion ratio of 1.11 which was followed by $\mathrm{T} 3$ and $\mathrm{T} 1$ with average fecd conversion ratio of 0.96 and 0.80 respectively. Statistical analysis revealed that there was no significant difference $(\mathrm{P}<0.05)$ in the feed conversion ratio of the fishes fed with the experimental diets. (Appendix III)

Table 4.1.6: Production costs of experimental diets:

\begin{tabular}{l|c|c|c} 
Variable & T1 & T2 & T3 \\
\hline Duration of the study (days) & 56 & 56 & 56 \\
\hline Number of fish/treatment & 30 & 30 & 30 \\
\hline Number of fish/replicate & 10 & 10 & 10 \\
\hline Cost of 1 juvenile fish $(\mathrm{N})$ & 10 & 10 & 10 \\
\hline Cost/Kg of feed $\mathrm{A} / \mathrm{kg}$ & 150 & 350 & 130 \\
\hline Cost/g of feed & 0.15 & 0.35 & 0.13 \\
\hline Average feed intake/fish $(\mathrm{g})$ & 3.94 & 3.06 & 2.38 \\
\hline Average welght gain/fish $(\mathrm{g})$ & 2.91 & 3.39 & 2.06 \\
\hline Average feed conversion ratio & 0.8 & 1.11 & 0.96 \\
\hline Total feed intake/fish $(\mathrm{g})$ & 31.52 & 24.48 & 19.04 \\
\hline Total cost of feeding $\mathrm{N}$ & 4.73 & 8.57 & 2.48 \\
\hline Other variables $\mathrm{N}$ & 2 & 2 & 2 \\
\hline Market price per $\mathrm{kg}(\mathrm{A})$ & 500 & 500 & 500 \\
\hline Market price per $\mathrm{g}(\mathrm{A})$ & 0.5 & 0.5 & 0.5 \\
\hline Average final weight per fish $(\mathrm{g})$ & 23.31 & 27.1 & 16.47 \\
\hline Revenue $\mathrm{A}$ & 11.66 & 13.55 & 8.24 \\
\hline Total cost of production & 12.15 & 12.35 & 12.13 \\
\hline Profit $(\mathrm{N}$ ) & 9.66 & 11.55 & 6.24 \\
\hline
\end{tabular}

The above table shows the production cost of experimental diet. Treatment 2 had the highest profit of N11.55 followed Treatment 1 with $\mathrm{N} 9.66$ while Treatment 3 had a profit of $\mathrm{N} 6.24$, this is as a result of the feather meal that was used to replace fish meal.

\section{Discussion}

Fish growth is influenced by various physiochemical parameters and nutrient availability in the water body. The level of nutrient may vary considerably. All fish species has different level of tolerance and lethal values to various environmental 
conditions prevailing in the ambient water body. Temperature plays a crucial role in fish production as high temperature help in high dissolve of oxygen. Huet (1972) recommended pH range of $7.0-8.0$ with less fluctuation is best for Tilapia. According to Boyd (1979) natural water that contains high alkalinity support more productivity than water of lower alkalinity. Tilapias are generally hardened and have a high tolerance level for alkalinity. The feed intake of the fish were not uniform from week one [1] to eight [8], fish under Treatment 1 had the highest feed intake than those of Treatment 2 and Treatment 3. The high feed intake observed among the treatment might be attributed to the protein requirement by juvenile tilapia which is within the range of 30-45\% crude protein (Gunasckera et al., 1996). The weight gain of the fish in Treatment 2 was higher than Treatment 1 and 3; the high weight gain of the fish in Treatment 2 might be attributed to the palatability and the floating nature of the feed. (NRC 1987, Pompa 1982) reported that high level of anti-nutrient can result in low consumption and high utilization. While treatment 3 had the lowest weight gain this might be attributed to the low palatability as a result of feather meal inclusion in the feed.

The feed conversion ratio in Treatment 2 was higher subsequently followed by T3 and T1. The considerable FCR recorded in this study agrees with result of (Maldonado et al (1979), Villarreal (1980) and Pastastico et al. (1982)) that fish reared in lower volume consumed less food and convert far less efficiently spending greater energy on surfacing resulting in low growth performance and vice versa. The survival rate were high in this experiment but the means were not significantly different $[\mathrm{P}>0.05]$. The high survival rates were partly attributable to the tolerable range of the physiochemical measurement during the experiment. The result of production cost showed that Treatment 2 is economical than other treatment in terms of profit gain followed by Treatment 1, while Treatment 3 is lease profit gain because of the feather meal inclusion. However, feather meal is not as profit rewarding in production of tilapia in glass tank as fish meal but the survival rate is considerable.

\section{Conclusion}

There was no significance difference $(P>0.05)$ in the weight gain, feed intake and feed conversion ratio of fish fed with the experimental diet. The highest feed cost was recorded in the imported pelletized feed while the lowest cost was observed in hydrolyzed feather meal inclusion feed. However, hydrolyzed feather meal cannot be used as an inclusion in Tilapia feeding ration as a source of protein because it is not economical in terms of production cost and also has low palatability. The result obtained with use of hydrolyzed feather meal as a fish meal replacer with aqua feeds for tilapia has been more controversial. However, Tacon et al. (1983), Viola and Zohar (1984) and Davies et al. (1989) all reported poor growth in tilapia when fed hydrolyzed feather meal base diet. While Bishop et al. (1995) reported that hydrolyzed feather meal could replace up to $50 \%$ and $66 \%$ of the fish meal within diet for $O$. niloticus fingerlings and fiy with no lost of growth performance. More so, Tilapia can be raised in glass tank because survival rate is bearable depending on the management.

\section{Recommendation}

More research should be carried out on how to improve method of processing local feed for better utilization.

\section{REFERENCES}

Adesalu, E. A. (2004). Nutrition in S. gallilaeus in Lake Kainji. PhD Thesis, University of Ife, Nigeria

Ayanwale B. A. (2006). Evaluation of feather meal as a protein source in rabbit diet. Federal University of Technology, Minna.

Bardach, J. E., Ryther, J. H. and Mclarney, W.O. (1972). Aquaculture (farming and husbandry of freshwater and marine organisms), 358.

Bishop, C. D., Angus, R.A. and Watts, A. (1995). The use of feather meal as a replacement for fish in the diet of O. niloticus fry. Bioresources Technology, 54:291-295.

Bowen, S. H. (2001). Digestion and assimilation of periphytic detrital aggregate by tilapia mossambia. Trans America Fish Society, 110pp 239-345.

Boyd, C. E. (1979): Water quality in warm water fish ponds. Agricultural Experiment Station, Auburn University, Alabama, 359p.

Davies, S. J., Williamson, J., Robinson, M. and Bateson, R. I. (1989). Practical inclusion levels of common animal by-products in complete diets for tilapia (O. mossambicus). Proc. 3rd Intl. Symp. on Feeding \& Nutr. in Fish, Toba, Japan, 325-332.

El-Sayed A. F. M. (1999). Alternative dietary protein source for farmed tilapia. Oreochromis spp. Aquaculture 179: 149-168.

Falaye, A. E. (1992). Utilization of agro industrial waste as fish feedstuff in Nigeria. Proceedings, 10th FISON Annual Conference, Abeokuta, 47-57.

FAO (2004). Fish Statatistics Plus Aquaculture Production 1950-2002.

Fagbento, O. A. (1987). Yield from monosex culture trails of Oreochronis niloticus in small farm ponds. Nigeria Journal of Basic and Applied Sciences, 2: 161-164

Gunasekera, K. F. and Lam, T. J. (1996). Effects of dietary protein level on spawning, performance and amino-acid composition of eggs of Nile tilapia. Aquaculture 146:121-134.

Huet, (1972). Texibook of Fish Cuiture, Breeding and Cultivation of Fish. Trns. H. Kohn. Surrey: Fishing News (Books) Ltd. 436p.

Jauncey, K. (1998). Tilapia Feeds and Feeding. Stirling, Scotland: Pisccs Press Ltd. 24lpp.

Maldonado, R. C, Pagan-Front, F. A (1979). Evaluation of policulture in plastic fish ponds utilizing channel catfish (Icatalurus punctatus) and blue tilapia (Sarotherodon aurea) fed with bird food. CARIB, Vol 14: 36 .

National Research Council (1987): Nutrient Requirement of Warm Water Fishes. National Academy of Science Washington D.C 78pp. 
Pantastico, J. B., Espegedara, C. and Reyes. D. (1982). Report on the polyculture of Sarotherodon niloticus and Prochilodus reti Kalikasan, 11/245-254.

Pompa J. J. (1982). Digestibility of selected feedstuffs and naturally occurring algal by tilapia, PbD, Auburn University, Alabam

Sullivan, T. W and Stephenson. E. L. (1957). Effect of processing method of the utilization of hydrolyzed poultry feathery grow chicks. Poult. Sci. 36, 361-365.

Tacon, A. G. J., Jauncey, K., Falaye, A., Pantha, M., MacGowon, I. and Stanford. E. A. (1983). The use of meat and bonemeal, hydrolyzed feather meal in practical fry and fingerlings diets for Oreochromis niloticus. Fishelson, $\mathrm{J}$. and Yaron, $\mathrm{Z}$. Proc.1st. Intl. Symp. on Tilapia in Aqualculture, Tel Aviv Univ. Press, 356-365.

Trewavas, E. (1999). Tilapia spp: Taxonomy and speciation, 3-13.

Villareal, Z. N. 1980, Culture of tilapia and Cyprinus in Fortaleza Bennales Pisco (Peru) Documenta. 8/74. 